\title{
Cães Renegados: judeus conversos portugueses do século XII*
}

\author{
Rui Bressiani Queirós de Faria** \\ Universidade do Porto \\ ORCID ID: https://orcid.org/0000-0003-4837-6106
}

Generalmente se acepta que la conversión de judíos al Cristianismo representa un fenómeno curioso, cuyo entendimiento permite esclarecer las dinámicas culturales y sociológicas entre las diferentes comunidades religiosas medievales. Sin embargo, ha sido un tema casi ignorado en la historiografía portuguesa moderna. Esto no solo dificulta una percepción más amplia de la propia comunidad judía portuguesa, sino que también impide nuevos y renovados ejercicios en el contexto de las relaciones entre cristianos y judíos durante la Edad Media. Este artículo intenta apreciar el fenómeno de la conversión al cristianismo durante el siglo XIII. Hablamos de la construcción de los primeros textos legales en relación a los conversos, las características de estas conversiones, las reacciones populares y de algunos ejemplos ilustrativos de conversiones y de conversos, a pesar de su aparente escasez.

Palabras clave: Portugal; judíos; conversos; derecho canónico; leyes de 1211.

Cães Renegados: Portuguese Jewish Conversos in the 13th Century.- It is generally accepted that the conversion of Jews to Christianity constitutes a curious phenomenon, the understanding of which allows us to clarify both the cultural and sociological dynamics between the different medieval religious communities. However, it has been an almost ignored theme in modern portuguese historiography. This not only hinders a broader perception of the Jewish community itself, but also prevents new and renewed exercises in the context of Christian-Jewish relations during the Middle Ages. This ar-

* Este trabalho é dedicado à memória da Professora Filomena Lopes de Barros (U. Évora), principal responsável pela sua feitura. Todas as qualidades e originalidades que este texto apresenta pertencem ao seu rigor e criatividade, cabendo-me inteiramente a responsabilidade por todos os seus desacertos e deslizes. Decerto quem teve o privilégio de se cruzar no seu caminho foi abençoado com as doses mais generosas de ternura e solidariedade - qualidades que contrariam tudo aquilo que uma sociedade actual nãosalutarmente competitiva e doentiamente não-solidária contém de negativo, e que faziam da Professora Filomena uma pessoa ímpar, cujo legado científico e humano de inquestionável importância ficará para sempre na nossa memória.

**queirosdefaria@sapo.pt

Copyright: (C) 2021 CSIC. Este es un artículo de acceso abierto distribuido bajo los términos de la licencia de uso y distribución Creative Commons Reconocimiento 4.0 Internacional (CC BY 4.0). 
ticle attempts to appreciate the phenomenon of conversion to Christianity during the 13th century, regarding the construction of the first legal texts in relation to converts, the characteristics of these conversions, popular reactions and some illustrative exemples of conversions and conversos, despite their apparent scarcity.

KeYwords: Portugal; Jews; Converts; Canon Law; Laws of 1211.

\section{INTRODUÇÃO}

Ao longo dos últimos anos, o tema das conversões medievais tem suscitado o interesse dos investigadores e originado muitos estudos ${ }^{1}$, com grande aproveitamento dos medievalistas peninsulares em particular, apesar do panorama da sua produção historiográfica espelhar duas realidades bastante díspares: por um lado, achega-se a imagem duma historiografia espanhola que lhe tem dedicado especial zelo e atenção, conhecendo muitos cultores ${ }^{2}$...; por outro, um cenário mais tímido em Portugal, de pobre cultivo e fraca divulgação, onde brota um ou outro contributo mais competente, quase exclusivamente subordinado a um caso de estudo mais amplo, o que impede exercícios de especialidade com o rigor desejado ${ }^{3}$.

Uma conjuntura historiográfica marcadamente pobre, que só conhece melhorias significativas à medida que percorremos as últimas décadas do medievo a passos largos, apontando para os séculos de $1500 \mathrm{em}$ diante, onde se erguem dois temas que viram surgir uma longa tradição historiográfica, que desde o século de Herculano tem produzido obras de grande calibre e rigor: a Inquisição e os «Cristãos-Novos» ${ }^{4}$. Uma tradição indiscutivelmente marcante, que mereceu a atenção dos maiores

1 Veja-se, mais recentemente, Yosi Yisraeli e Yaniv Fox, Contesting Inter-Religious Conversion in the Medieval World (Londres: Routledge, 2007), e Cecil D. ReID, Jews and Converts in Late Medieval Castile: Breaking with the Past (London: Routledge, 2021).

2 Isabel Montes Romero-CAmacho, «El problema converso. Una aproximación historiográfica (1998-2008)», Medievalismo 18 (2008) págs. 109-247.

${ }^{3}$ Por exemplo, Maria José Ferro Tavares, Os Judeus em Portugal no Século XV (Lisboa: Universidade Nova de Lisboa, 1982) págs. 431-444, e Maria Filomena Lopes de Barros, $A$ Comuna Muçulmana de Lisboa: sécs. XIV e XV (Lisboa: Hugin, 1998) págs. 148-152.

${ }^{4}$ Um panorama bibliográfico bastante completo foi esboçado por Joaquim Romero MagalhãEs, «La Inquisición portuguesa: intento de periodización», Revista de la Inquisición 2 (1992) págs. 71-94. 
vultos da historiografia portuguesa, entre eles João Lúcio de Azevedo, António Baião, António José Saraiva, Jorge Borges de Macedo e Joaquim Romero Magalhães. Mais ainda, uma tradição que alcançou a proeza de romper inclusivamente com a fronteira literária ${ }^{5}$, daí surgindo páginas memoráveis dos mais exímios prosadores portugueses:

Riba Dal é terra de judeus. Pelo ano fora, o Padre João benze, perdoa, baptiza e ensina o catecismo por perguntas e respostas. «Quem é Deus?»- «É um Ser todo poderoso, criador do Céu e da Terra». Uma firmeza tal na voz daqueles cristãos, que não há quem possa desconfiar que por detrás da sagrada cartilha está plantado em sangue o Pentateuco. Mas está. E à hora da morte, quando a um homem tanto lhe importa a Thora com os Evangelhos, antes de o Padre João vir dar os últimos retoques à pureza da ovelha, para que no derradeiro arranco a língua não abra mão daquele segrêdo - abafador ${ }^{6}$.

Mas qual o protagonismo que as conversões medievais ocupam nesses estudos supracitados? Superficial e incompleto - pelo menos quanto seria desejável-, são duas características marcantes; pois o comum estabelecimento do limite $a$ quo das investigações em torno da segunda metade do século XV implica, desde logo, a exclusão de uma larga parcela cronológica (que inclui este século XIII de que tratamos, e não só.). Com isto, o judeu converso português adquire vida curta, evoluindo rapidamente para o «cristão-novo» da modernidade Quinhentista, onde o seu testemunho surge plasmado nos expressivos processos da Inquisição, cuja enormidade e riqueza, pelo testemunho de António José Saraiva, «faz as delícias aos eruditos» ${ }^{7}$. Nos estudos que se dedicam à Inquisição, por exemplo, o converso medieval ocupa o lugar do intróito ou da breve contextualização temática, conhecendo, por isso, pouco ou nenhum desenvolvimento próprio ${ }^{8}$.

Ora, é fundamentalmente através da documentação, no seu duplo aspecto quantitativo e qualitativo, que vamos buscar a explicação para esta evolução tardia no panorama português. Em boa verdade, os testemunhos manuscritos relativos a judeus e conversos adquirem uma têm-

\footnotetext{
5 Sem cair de «moda».

${ }^{6}$ Miguel Torga, Novos Contos da Montanha (Coimbra, 1944) pág. 7. Em edições posteriores, o texto sofreu pequenas alterações de vocabulário, mas o essencial manteve-se.

7 António José SARaiva, Inquisição e Cristãos-Novos (Porto: Editorial Inova, 1969) pág. 11 .

8 É este o caso da larga maioria das obras dos supracitados autores. 
pera mais sistemática quanto mais avançamos pela cronologia medieval - onde o século XV se ergue com natural destaque. Também porque o número de judeus residentes no reino sofreu de um exponencial crescimento ao longo do princípio desse século, à conta das sucessivas vagas de famílias judaicas que em Portugal procuraram refúgio após as perseguições de 1391, vindas de Castela e Aragão. Há autores que falam num quintuplicar dos números - e isso materializa-se na multiplicação das aljamas um pouco por todo o reino ${ }^{9}$. Não há modo, porém, de contabilizar valores exactos, mas julgam-se expressivos ${ }^{10} \ldots$ Com isto, podemos concluir: o judeu medieval português surge, no século Xv, com mais frequência, e os testemunhos enriquecem o seu valor - um enriquecimento em quantidade, mas também em qualidade. São atributos que justificam, pois, a escolha de muitos especialistas em traçar o limite $a$ quo dos seus trabalhos em torno da segunda metade de Quatrocentos.

Vejamos o caso das conversões ao Cristianismo: as informações recolhidas por Maria José Ferro dão conta de um número de conversos mais expressivo em 1497 do que nas oito décadas anteriores ${ }^{11}$. Um dado que não espanta; pois essas conversões, à luz do prisma político que assolou a comunidade judaica nos últimos anos do século XV, fruto das expulsões e conversões em massa em Espanha e Portugal, foram maioritariamente de carácter forçado ${ }^{12}$. Assinala-se, assim, um contraste com a situação vivida neste século XIII, que conheceu um menor número de judeus a residir no reino, como também um menor número de judeus a converteremse ao Cristianismo. A juntar uma conjuntura política que não praticava uma assimilação dura da sua minoria judaica, preferindo antes uma manutenção bem delineada, naturalmente condicionada pelos princípios canónicos e civis, e também por uma mentalidade colectiva que reconhecia no judeu uma identidade palpável no horizonte quotidiano, pertencente a uma sociedade plural e heterogénea, o que levou aos monarcas portugue-

9 Tavares, Os Judeus em Portugal no Século XV, vol. 1, pág. 43.

10 Maria José Ferro TAvares, Inquisição e Judaísmo. Estudos (Lisboa: Editorial Presença, 1987) pág. 23.

11 Maria José Ferro Tavares, Os Judeus em Portugal no Século XV, vol. 2 (Lisboa: Instituto Nacional de Investigação Científica, 1984) págs. 870-907.

12 François Soyer, The Persecution of the Jews and Muslims of Portugal (Leiden: Brill, 2007). 
ses, não raras vezes, a considerá-los «seus», ficando esses judeus na alçada do seu proteccionismo, mas também da sua justiça.

De facto, há que suspeitar que o judeu medieval procurasse o baptismo somente em caso de última necessidade, como salvaguarda da própria vida, ou perante uma irrecusável oportunidade de melhoria das suas condições socioeconómicas. É de crer, aliás, que a maioria dos conversos era composta por indivíduos marginalizados que, pela asserção de Paola Tartakoff, num estudo que dedica à temática, «turned do baptism primarily as a means of escaping personal difficulties» ${ }^{13}$. $\mathrm{O}$ baptismo parece ter sido, então, a vida preferida dos mais pobres e desfavorecidos, a quem a apostasia representava a esperança da tão-desejada estabilidade que todo o homem medieval procurava - baptismo esse que prometia uma vida livre dos percalços que a condição anterior carregava. É de crer que muitos destes conversos haviam adquirido um estatuto de persona non grata no seio das suas comunidades. Problema que os ricos e influentes decerto não sofriam, à conta do seu estatuto.

Baptismo, portanto, como fuga. Coisa razoável. Pese embora as notícias de que muitos conversos regressavam ao seu antigo credo, já que «they would never find a place in Christian society, let alone be perceived as bona fidei Christians» ${ }^{14}$.

É por causa da escassez documental já assinalada que o trabalho em busca pelo converso de Duzentos faz-se com recurso a dados secundários e muito esporádicas: informação dispersa, que o investigador recolhe como autênticas migalhas. E embora esta primeira impressão lhes possa conferir um carácter desanimador, impeditivo quase, a verdade é que esses dados oferecem ainda bastantes vias de problematização e outras tantas hipóteses de análise; ou seja, resguardando-me no eco da tradição popular, «dão muito pano para mangas» ${ }^{15}$. É este o caso das

13 Paola TartakofF, «Testing Boundaries: Jewish Conversion and Cultural Fluidity in Medieval Europe, c. 1200-1391», Speculum 90:3 (2015) págs. 728-762.

14 TARTAKofF, «Testing Boundaries», pág. 754.

15 «É uma tradição estabelecida e que se tornou já em certa medida maçadora, entre os medievalistas (e alguns modernistas), a chamada 'lamentação sobre as fontes desaparecidas'. Num recente encontro científico, os investigadores presentes fizeram mesmo uma promessa simbólica: nunca mais nos queixaríamos dos documentos que não temos - pelo menos até estudarmos bem todos os que temos, o que está ainda muito 
chamadas fontes do Direito, cujos testemunhos dispersos, mas seguros, fui paulatinamente recolhendo: ordenações, posturas municipais, sínodos, entre outros. Fontes essas que já mereceram a atenção dos especialistas em variados estudos e temáticas, mas que nunca figuraram nos tubos de ensaio calibrados para o problema dos conversos ${ }^{16}$. Recorrendo a esses testemunhos, somos capazes de observar a construção jurídica do estatuto do converso, além de atestar os ecos da contestação dos que viam judeus tornarem-se cristãos: falo, naturalmente, dos vários insultos que lhes eram arremessados, e que a documentação deste século XIII dá conta. Não me poderei esquecer, também, dos vários registos de escravos muçulmanos que, à data da sua libertação, convertiam-se à fé de Cristo, usualmente como condição para a sua liberdade; estes casos particulares já mereceram a análise cuidada de François Soyer ${ }^{17}$, sem desprezar as contribuições mais antigas, igualmente marcantes, de António Losa ${ }^{18}$.

Porém, e falando na generalidade, pisamos em solo inédito. Inédito não só pelas características da própria documentação -tímida, como se viu-, mas também por não se terem desenvolvido esforços no sentido de inverter essa tendência. Este último é o propósito do trabalho que aqui se apresenta, apontando exclusivamente para o primeiro momento do converso português, que é o século de 1200 .

\section{Na esfera do Direito Canónico}

A ocorrência de conversões ao Cristianismo pôde certamente ser testemunhada um pouco por todo o Ocidente europeu, com uma parti-

longe de acontecer»; $c f$. Luís Miguel Duarte, «O Portugal que foi a Ceuta: certezas e dúvidas», Aveiro e a Expansão Marítima Portuguesa, 1400-1800. Atas das $8^{a}$ S Jornadas de História Local e Património Documental (Aveiro-Lisboa: Câmara Municipal de Aveiro-Âncora Editora, 2017) págs. 17-39: 17-18.

16 São trabalhos incontáveis, produzidos em praticamente todas as épocas da historiografia portuguesa.

17 François Soyer, «Muslim Slaves and Freedmen in Medieval Portugal», AlQanțara 28:2 (2007) págs. 489-516.

18 António Losa, Entre Cristãos, Mouros e Judeus: do Minho ao Mar das Índias (colectânea de estudos de António Losa), coord. António Manuel LÁzAro (Braga: Lab2PT, 2018). 
cular incidência nos vários pontos de passagem da diáspora hebraica, e também nas regiões ditas «de fronteira», na região mediterrânica, onde predominava a coexistência entre cristãos e muçulmanos. À Península Ibérica pertencia o grande protagonismo dessa mesma coexistência, juntando num amplo espaço - «de brisas deliciosamente perfumadas», como the chamavam os poetas daquele tempo ${ }^{19}$-, cristãos, judeus e muçulmanos, tal palco multicultural de sociabilidades com múltiplos e complexos contornos, ora pacíficos, ora violentos...; ora de integração, ora de exclusão...; ora de diálogo, ora de repreensão ${ }^{20}$. Pois a convivência humana não conhece traço linear, nem existências apáticas.

Nesse Ocidente europeu de maioria cristã, a conversão do outro ocupava um lugar cimeiro no programa teológico da Igreja, que durante séculos promoveu sucessivas políticas de assimilação das gentes descrentes. Pois converter os infiéis e espalhar o Evangelho era uma obra de misericórdia, que dependia inteiramente da aceitação voluntária por parte de quem a recebesse. Esperava-se, assim, que o judeu aceitasse o seu baptismo de bom grado, com braços abertos e mente límpida, sem que por detrás desse acto estivessem guardadas pretensões de ascensão social e material. Há muito que as conversões desonestas se revelavam uma queixa recorrente dos prelados, como é testemunhado nos registos de vários concílios ecuménicos medievais. No $4^{\circ}$ Concílio de Toledo (633), por exemplo, há denúncias da prática obscura da circuncisão por parte de judeus que se fizeram baptizar, pelo que se ordenava a separação dos filhos desses delinquentes ${ }^{21}$; e mais tarde, no $2^{\circ}$ Concílio de Niceia (787), repete-se uma semelhante acusação: «os adeptos da religião judaica, transviados, julgam por bem ridicularizar a Cristo Deus,

19 Extracto dum poema de Ibn Jafaya, do século XI. Veja-se Henri Pérès, Esplendor de al-Andalus, trad. espanhola de Mercedes GarcíA-Arenal (Madrid: Ediciones Hiperión, 1990) pág. 122.

${ }^{20}$ Maria Filomena Lopes de BArros, «Judeus e muçulmanos no espaço urbano: inclusões, exclusões e interações», em Inclusão e Exclusão na Europa Urbana, eds. Amélia Aguiar Andrade, Catarina Tente, Gonçalo Melo da Silva e Sara Prata (Lisboa: Instituto de Estudos Medievais, 2019) págs. 89-112.

21 Joaquim de Assunção Ferreira, Estatuto Jurídico de Judeus e Mouros na Idade Média Portuguesa (Lisboa: Universidade Católica Editora, 2006) pág. 86. 
simulando que são cristãos, mas o renegam a observarem na sombra e às ocultas o Sábado e outros costumes...» ${ }^{22}$.

Porém, a própria promoção dessa conversão não estava isenta de métodos e meios. Acima de tudo, deveria ser conduzida dum modo complacente, através do diálogo apologético ${ }^{23}$, com pregações junto a sinagogas, ou no adro de determinadas igrejas ${ }^{24}$. Ou seja, pelas palavras de Afonso X, o Sábio, «con buenos exemplos, et con los dichos de las santas escripturas»; pois «ca nuestro señor Dios non quere nin ama servicio quel sea fecho por fuerza» ${ }^{25}$. Conversão sincera e voluntária. Fundamentalmente.

Como mais adiante veremos, este conjunto de práticas veio a tornarse num autêntico modus operandi para futuras conversões, cuja promoção era vigiada pelo olhar atento e observante do Papado que, não raras vezes, via-se na posição de condenar acções contrárias. Assim se impunha o dever do pontífice. Foi este o caso, já amplamente divulgado, da repreensão das acções dos bispos de Marselha e Arles, em cujas dioceses os judeus eram coagidos a aceitar as águas do baptistério - contrariando, assim, as determinações canónicas vigentes e a própria vontade do pontífice, Gregório Magno ${ }^{26}$.

Provinha a protecção papal da minoria judaica de várias tradições teológicas, todas podendo atribuir os seus cânones à influência da Carta aos Romanos, de São Paulo ${ }^{27}$. Diz-nos o Apóstolo que a promessa da conversão de Israel aquando do Dia do Juízo Final advinha

22 Ferreira, Estatuto Jurídico, pág. 138.

23 Embora o número real de conversos que se baptizaram à custa dos discursos apologéticos tivesse sido bastante tímido, como explica TARTAKOFF, «Testing Boundaries», págs. 740-744.

24 José Leite de Vasconcelos, Etnografia Portuguesa, Vol. IV (Lisboa: Imprensa Nacional, 1958) pág. 114.

25 Partida VII, Título XXIV "De los judios", Ley VI. Consulte-se Las Siete Partidas del Rey Alfonso El Sabio, cortejadas com varios codices antiguos por la Real Academia de la Historia, Tomo III (Madrid: Editorial Atlas, 1807) pág. 672.

26 Jacob R. Marcus, The Jew in the Medieval World. A Source Book: 315-1791 (New York: Atheneum, 1974) págs. 111-114.

27 Epístola aos Romanos 11,25-29. Veja-se A Bíblia. Novo Testamento: Apóstolos, Epístolas, Apocalipse, ed. e trad. por Frederico Lourenço, vol. II (Lisboa: Quetzal Editores, 2017). 
do papel central que desempenham os judeus na tradição teológica cristã como testemunhos vivos do Antigo Testamento, demonstrando, pois, «como a Igreja de Cristo, ao acolher os pagãos, não perdeu as suas raízes no povo cuja eleição começa em Abraão; pelo contrário, só quando todos, pagãos e judeus, aderirem a Cristo, se cumprirão plenamente as promessas de Deus» ${ }^{28}$. Havia então que promover um mantimento dos judeus no seio da própria Cristandade, para que pudessem cumprir o seu papel no plano divino, até à sua eventual salvação, como prometido na Carta aos Romanos ${ }^{29}$. Mantimento esse teologicamente apartado, é certo, para evitar o prejuízo dos fiéis de Cristo; e se esses judeus procurassem a conversão ao Cristianismo mais cedo, um tanto melhor.

Por influência desta mesma tradição paulina, e também das reflexões posteriormente tecidas a este respeito por Santo Agostinho ${ }^{30}$, um rol de medidas verdadeiramente marcantes foi consumado durante o pontificado de Gregório Magno. Num conjunto de epístolas que dedicou ao tema, sobressai a Sicut Iudaeis, cujo teor estabelece uma lista de princípios fundamentais para assegurar a protecção dos judeus e da sua propriedade $^{31}$. São eles os seguintes ${ }^{32}$ :

1.- Não matar judeus;

2.- Não forçar o seu baptismo;

3.- Respeitar os seus usos e costumes;

4.- Não violar os seus templos, nem cemitérios, nem propriedade.

De tal forma marcantes, o seu conteúdo foi depois compilado pela pena de Graciano no seu Decretum, e confirmado por diversos pontífices

28 Bíblia. Novo Testamento, 2a . edição (Lisboa: Difusora Bíblica, 2000), pág. 551.

29 Rebecca Rist, Popes and Jews, 1095-1291 (Oxford: Oxford University Press, 2016) pág. 73.

30 A este propósito, veja-se o artigo de Michael Frassetto, «Augustine's Doctrine of Witness and Attitudes toward the Jews in the Eleventh Century», Church History and Religious Culture 87 (2007) págs. 287-304. Para uma visão mais abrangente, consulte-se a obra de Paula Fredriksen, Augustine and the Jews: A Christian Defense of Jews and Judaism (New Haven-London: Yale University Press, 2010).

31 Rist, Popes and Jews, pág. 78.

32 Jeremy CoHEn, Living Letters of the Law. Ideas of the Jew in Medieval Christianity (Berkeley: University of California Press, 1999) págs. 73-95. 
medievais, até bem perto do crepúsculo do século $\mathrm{XV}^{33}$. Há que notar que os próprios cânones dos concílios gerais da Baixa Idade Média atestam, com frequência, o eco da tradição gregoriana ${ }^{34}$; as Decretais de Gregório IX, ou Liber Extra de 1234, retomam muitos dos seus parâmetros, ainda que sob influência clara do $4^{\circ}$ Concílio de Latrão de $1215^{35}$; e a compilação dos princípios gregorianos nas Ordenações Afonsinas do século $\mathrm{XV}$, a pedido da própria comunidade judaica de Lisboa, permite confirmar o seu impacto na longa duração ${ }^{36}$.

Há fortes razões para suspeitar, a propósito do Liber Extra de 1234, que o sínodo olisiponense de 1271, outorgado pelo bispo Dom Mateus, tenha surgido à luz das determinações gregorianas recentemente renovadas por Gregório IX. Vejamo-lo de perto:

Si Iudeus uel Sarracenus sacri baptismatis lauacro desiderat expiari, baptizans prius consideret et exploret an amor fidei christiane an alia quauis causa illicita ad huiusmodi instantiam petitionis eum aduocet et inducat. Quod si illum decreuerit baptizandum religioso uiro uel loco episcopus uel eius uicarius deputet in fide instruendum ac moribus informandum. Quod si egestate dignosticur laborare pre sul tam de suo quam de hiis que a populo per exhortationem sibi poretir adipisci neccessaria mediocriter administret, ne pro necessariorum defectu cum Christi cultoribus peior fiat quam cum occisoribus existebat. In aliqua etiam ecclesia arte mecanica instruatur ut discat aliis exhibere unde ipsi ualeat exhiberi ${ }^{37}$.

Como se denota, o sínodo estabelece as bases dum autêntico modus operandi para conduzir as conversões de judeus e muçulmanos, atestando as boas práticas que anteriormente vimos: conversão livre, con-

33 Rist, Popes and Jews, pág. 75.

34 Ferreira, Estatuto Jurídico, págs. 135-151.

35 Saul António Gomes, "Os Judeus no Reino Português (Séculos XII-XIII), em Minorias Étnico-Religiosas na Península Ibérica: Período Medieval e Moderno, coords. Maria Filomena Lopes de Barros e José Hinojosa Montalvo (Évora: Publicações CIDEHUS, 2008) págs. 79-91.

36 Ordenações Afonsinas, ed. fac-simile da edição feita pela Real Imprensa da Universidade de Coimbra, no ano de 1792 (Lisboa: Fundação Calouste Gulbenkian, 1984) Livro II, título $94^{\circ}$, págs. 514-520.

37 Publicado por José Antonio García y García, Synodicum Hispanum. Vol. II: Portugal (Madrid: Biblioteca de Autores Cristianos, 1982) pág. 304. 
versão sincera. Ora o infiel que desejasse tomar as águas do baptistério teria primeiro de demonstrar uma sinceridade inabalável da sua convicção, renegado quaisquer pretensões forçadas e/ou interesses calculistas ${ }^{38}$ (Si Iudeus uel Sarracenus sacri baptismatis lanacro desiderat expiari, baptizans prius consideret et exploret an amor fidei christiane an alia quauis causa illicita ad huiusmodi instantiam petitionis eum aduocet et inducat.) Aprovado o seu baptismo, ficaria à guarda de um ou mais fiéis, para que pudesse receber a instrução na fé cristã, essencial para o seu novo enquadramento social ${ }^{39}$; acima de tudo, presume-se que lhe fossem transmitidas as orações, como o Pater Noster e a Avé Maria. Uma medida expectável, já muito antiga ${ }^{40}$. Seguidamente, os conversos seriam acompanhados num determinado ofício mecânico, trabalhando como aprendizes, se assim fosse o caso, para que pudessem depois gozar de um sustento próprio. Era, assim, necessário garantir um futuro viável para os que procurassem a fé de Cristo - para que a sua vida cristã fosse invariavelmente melhor da que era lavada pelas águas do baptistério ${ }^{41}$. Caso contrário, como garantir que não retomassem a prática do seu antigo credo? É de notar que volvidos dois séculos da celebração deste sínodo, também na Guarda se retomava a mesma preocupação, embora num contexto marcadamente distinto ${ }^{42}$.

Atente-se, porém, que nem sempre esta assimilação adquiriu contornos pacíficos e concordantes com a boa prática cristã. Apesar da sua proibição no $3^{\circ}$ Concílio de Latrão $(1179)^{43}$ e no Liber Extra $(1234)^{44}$, a expropriação dos bens dos conversos manteve-se prática comum na Inglaterra de Henrique III (1216-1272), como atesta Robert Stacey ${ }^{45}$. E

38 Ferreira, Estatuto Jurídico, pág. 235.

39 TARTAKoff, «Testing Boundaries...», pág. 736.

40 Já discutida nos Concílios Trullano (692) e Agatense (506); cf. FerreIra, Estatuto Jurídico, pág. 156.

41 Já determinado pelo $3^{\circ}$ Concílio de Latrão (1179); $c f$. FerReIra, Estatuto Jurídico, pág. 142.

42 Sínodo da Guarda de 1500; cf. Ferreira, Estatuto Jurídico, págs. 331-332.

43 Ferreira, Estatuto Jurídico, pág. 142.

44 Ferreira, Estatuto Jurídico, pág. 160.

45 Robert C. STACEY, «The Conversion of Jews to Christianity in Thirteenth-Century England», Speculum 67 (1992) págs. 263-283: 266. 
também neste Portugal de Duzentos correm notícias de que Dom Dinis (1279-1325) envolveu-se em semelhantes hábitos, tal como vem descrito num ponto da Concordata dos 40 Artigos, posteriormente compilada nas Ordenações Afonsinas, do século Xv. Porém, a acusação de que este monarca espoliava os bens dos conversos foi categoricamente negada pelos procuradores régios, chegando estes mesmos a prometer que doravante «não o consentiriam, mandando corrigir quaisquer abusos que descobrissem nesta parte» ${ }^{46}$.

\section{As LEIS DE 1211}

Porque as minorias religiosas constituíam uma manifesta realidade no quotidiano medievo, havia que regulamentar com todo o cuidado a acção da sua sociabilidade, o que passava, naturalmente, pela criação de um estatuto jurídico próprio - temática que já motivou muitos estudos da crítica portuguesa e estrangeira, com maior peso desta última ${ }^{47}$. Criação essa baseada em moldes mais antigos, já testados e comprovados, como é o caso do Direito Romano e do Código Visigótico -e, até certo ponto, a própria lei islâmica ${ }^{48}$; mas é indiscutível a influência exercida pela Lei Canónica, como teremos oportunidade de ver.

Um dos primeiros esforços que visou essa mesma regulamentação ocorreu, em Portugal, no alvorecer do século XIII -mais precisamente em 1211, aquando da reunião extraordinária da Cúria Régia, convocada pelo recém-coroado Dom Afonso II (1211-1223). É bem-sabida a conjuntura política desfavorável durante os últimos anos do reinado do seu pai: divergências e disputas com o Clero e a Nobreza, que duravam há muito.

46 Ordenações Afonsinas... Livro II, título $1^{\circ}$, pág. 29; cf. FERREIRA, Estatuto Jurídico, págs. 248-249.

47 Em 2015, ficou concluído um projecto de estudo do estatuto legal das minorias religiosas no mundo europeu e mediterrâneo, entre os séculos VI e XVI (REMLIN). Vejase John Tolan, "The Legal Status of Religious Minorities in the Euro-Mediterranean World (RELMIN)», Medieval Worlds 1 (2015) págs. 148-166. Para uma listagem bibliográfica mais completa sobre esta temática, consulte-se: <https://cordis.europa.eu/project/ $\mathrm{id} / 249416 /$ results $>$ [acesso a 03/03/2021].

48 Ferreira, Estatuto Jurídico, págs. 102-131. 
Pesada bagagem, que o jovem monarca necessitava de esvaziar ${ }^{49}$. Fá-lo sem demoras, escassos meses após o falecimento de Dom Sancho I (11851211), entre Abril e Junho desse mesmo ano, convocando para Coimbra o arcebispo de Braga, Dom Pedro, juntamente com «todos os bispos do rreyno e dos homens de rreligiom e dos ricos homens e dos seus vasalos» ${ }^{50}$.

É da opinião consentida dos especialistas que o resultado mais tangível dessa primeira reunião da Cúria Régia foi a promoção das chamadas «leys geraes pera todo o Reyno», primeiras do seu género, pese embora já tenham inspirado acesos debates no meio académico ${ }^{51}$. Porém, para a posteridade teceu-se a imagem dum rex legislator que, apesar da defesa dos privilégios do Clero e da Nobreza, deixa bem claro, preto no branco, com regras claras e escritas, a quem pertencia o exercício governamental e a aplicação da justiça ${ }^{52}$. Pois pela promoção de regras criou a ordem; e da ordem nascerá a primeira concretização duma Nação orgânica ${ }^{53}$.

Infelizmente, a passagem do tempo ditou um destino infeliz para os originais manuscritos das leis de 1211: desconhecemos quaisquer registos, salvo aquilo que foi posteriormente copiado nos séculos XIV e XV

49 Hermínia Vilar, D. Afonso II: um rei sem tempo (Lisboa: Círculo de Leitores, 2005) págs. 75-79.

50 Portugaliae Monumenta Historica, Leges et Consuetudines, vol. 1, fasc. 2 (Lisboa: Academia das Ciências de Lisboa, 1861) pág. 163.

${ }^{51}$ Recorde-se as opiniões divergentes de José Matтoso («A Cúria régia de $1211 \mathrm{e}$ o direito canónico», Direito e Justiça. Revista da Faculdade de Direito da Universidade Católica Portuguesa 12 [1988] págs. 4-26), e de Nuno José Espinosa Gomes DA SiLva («Ainda sobre a lei da Cúria de 1211 respeitante às relações entre as leis do Reino e o direito canónico», Clio: Revista do Centro de História da Universidade de Lisboa 6 [1987-88] págs. 29-38). O carácter sociológico destas prerrogativas já foi ensaiado por Maria Fernanda Maurício, «As leis de 1211 - alguns "princípios" sociológicos», em Actas das 2. 'Jornadas Luso-Espanholas de História Medieval. Vol. 3 (Centro de História da Universidade do Porto, 1989) págs. 893-905.

52 Maria Helena DA CRUz Coelho, «As cortes no reino de Portugal: antecedentes e concretizações», em A escrita da História de um lado a outro do Atlântico, orgs. Maria Eurydice de Barros Ribeiro e Susani Silveira Lemos França (São Paulo, Cultura Acadêmica, 2018) págs. 43-61.

53 Sobre a concepção de ordem e a sua relação com a construção identitária do território, veja-se Armindo de SousA, «Condicionamentos Básicos», História de Portugal, vol. 2, coord. José Matтoso (Lisboa: Editorial Estampa, 1994) págs. 313-386: 360. 
nas grandes colectâneas do direito medieval português, seja no Livro das Leis e Posturas, seja nas Ordenações de Dom Duarte ${ }^{54}$. Tratando-se de cópias, é natural que a crítica duvidasse da sua providência ${ }^{55}$, temendose, pois, uma desvirtuação das disposições originais. Como explicou José Mattoso, falta homogeneidade na tradição discursiva do conjunto, embora o próprio garanta que «os seus pressupostos gerais...», a respeito do seu conteúdo, «estão em perfeita consonância com a época» ${ }^{56}$.

Mas deixemos para outros palcos a discussão filológica acerca da origem deste rol documental e concentremo-nos no tema em mãos. Vejamos, então, com maior detalhe, a lei $26^{\mathrm{a}}$, que diz respeito a judeus e muçulmanos:

Porque aqueles que som honrrados polo sancto baptismo nom deuem a sseer agrauados dos judeus. Os quaaes nós assy como testemunho da morte de Jhesu Christo deuem a sseer defesos solamente por que som homeens. Poren mandamos e estabeleçemos que nem nós nem nossos suçessores nom façam judeu nem mouro nosso ouençal nem lhis cousa encomendar perque os christaãos en alguma cousa sseiam agrauados. E pero nom defendemos aos outros que lhis os seus seruiços possam encomendar. Item defendemos aos judeus e aos mouros sô pena de quato ouuerem que nom aiam per sergentes en sas casas homens christaãos nem molheres liures nem sseruas. E se contra nosso mandamento quiserem hir perçam quanto ouuerem. E sô esta meesma pena defendemos que nenhuum judeu nem mouro o filho que ouuer for tornado aa fé de Christo que o nom exerdem mais sol que for tornado nom sseia tornado a uiuer antre seus parentes. E outrossy defendemos que depois que o judeu ou mouro for tornado aa fé de Jhesu Christo que nom torne aa fé

54 Vejan-se Livro de Leis e Posturas ed. Nuno José Espinosa Gomes da Silva (Lisboa: Faculdade de Direito da Universidade de Lisboa, 1971) págs. 121-122, e Ordenações de Dom Duarte, eds. Martim de Albuquerque e Eduardo Borges Nunes (Lisboa: Fundação Calouste Gulbenkian, 1988) págs. 52-53. Ambas estão disponíveis online em: $<\mathrm{http}: / /$ www.governodosoutros.ics.ul.pt/> [acesso a 20/02/2021].

55 Maria João Violante Branco, «The general laws of Afonso II and his policy of "centralisation": a reassessement», em The propagation of power in the Medieval West, eds. M. Gosman et. alii (Groningen: Egbert Frosten, 1997) págs. 79-95.

56 José Mattoso, Identificação de um País: Oposição e Composição (Lisboa: Círculo de Leitores, 2015) pág. 644. 
que ante tiinha. E se o fezer perça a cabeça se depois que for amoestado nom sse quizer tornar ou emendar ${ }^{57}$.

Sem grande dificuldade, é possível perceber a asserção principal desta lei, que passa pelo estabelecimento da sociabilidade do outro no espaço cristão. Com efeito, erguem-se barreiras onde necessário, para protecção da própria Cristandade; mas também abrem-se excepções, para seu próprio benefício. É de notar, também, a profunda influência do direito canónico na elaboração destas prerrogativas, como aliás vem plasmado no prelúdio que abre o discurso: «Porque aqueles que som honrrados polo sancto baptismo nom deuem a sseer agrauados dos judeus»». Ora, esta asserção traduz-se sobretudo na protecção dos cristãos contra o malefício dos infiéis, particularmente dos judeus, cuja cumplicidade no julgamento e morte de Cristo permanecia ainda bem assente na memória colectiva do homem medieval. Isto impedia as gentes hebraicas de exercerem qualquer domínio sobre os fiéis de Cristo; havia, pois, que manter o outro numa posição apartada, longe de cargos públi$\cos$ e da posse de escravos cristãos ${ }^{58}$. Mas a sua preservação, como vimos, deveria partir dum sentimento estritamente humanitário, pois os judeus «deuem a sseer defesos solamente por que som homeens». Tradição da Carta aos Romanos, como já tivemos oportunidade de observar; e que havia merecido a atenção dos prelados no recém-celebrado $3^{\circ}$ Concílio de Latrão (1179): «é preciso que eles [os judeus] sejam submetidos aos cristãos e que estes os protejam por pura humanidade» ${ }^{59}$. Mas esta asserção não deixa de reflectir um sentimento de superioridade cristã face aos seus congéneres judeus e muçulmanos - superioridade essa de carácter teológico, mas também de carácter moral. Assim explicavam os diversos tratados apologéticos que surgiam um pouco por toda a Europa, incluindo Portugal; temos o caso do Tratado Teológico em que se prova a verdade da religião de Jesus Christo, a falsidade da Lei dos

57 Portugaliae Monumenta Historica, Leges et Consuetudines, vol. 1, fasc. 2, págs. 178-179.

58 Note-se que já no Breviário de Alarico (século VI) se retomavam as leis romanas tardias a propósito da proibição dos judeus possuírem escravos cristãos; $c f$. FERREIRA, Estatuto Jurídico, págs. 80-81.

59 Ferreira, Estatuto Jurídico, pág. 142.

SEFARAD, vol. 81:1, enero-junio 2021, págs. 43-68. ISSN: 0037-0894. https://doi.org/10.3989/sefarad.021-003 
judeus e a vinda do Messias, redigido durante o reinado de Dom Dinis ${ }^{60}$. Título longo. Título sugestivo.

A proibição do exercício de cargos públicos era já uma determinação antiga, discutida pelo menos desde o $4^{\circ}$ Concílio de Latrão (633), pois, «com esta ocasião, [os judeus] cometem injustiças contra os cristãos» ${ }^{61}$. Decerto seria penalizador para esses cristãos verem os seus tributos, provenientes do seu labor, esforço e suor, serem recolhidos por judeus; de facto, não era assunto que fosse tomado de leve. Por estarem proibidos de exercerem cargos públicos, aos judeus estava consequentemente vedado o serviço directo ao monarca, fosse como funcionários régios, ou em qualquer outra circunstância. Determinação essa que, não obstante, caiu rapidamente em desuso - desconhecemos se fruto do esquecimento, se fruto duma ignorância premeditada. É bem conhecido o caso que envolveu Dom Sancho II - que preferia a nomeação de judeus para o exercício de cargos públicos no bispado de Lisboa -, e o pontífice Gregório IX - que, dirigindo-se aos bispos de Astorga e Lugo, exigiu ao monarca português o cumprimento das determinações do concílio geral de Latrão de $1215^{62}$. Porém, parece que o efeito dissuasivo não foi duradouro. Em 1265, os arcebispos do Porto, Coimbra, Braga e Viseu, juntamente com os procuradores de Lamego e Évora, enviaram um amplo rol de queixas a Clemente IV; entre elas, a acusação de que o rei «investia os judeus em cargos públicos que lhes davam autoridade sobre os cristãos» ${ }^{63}$. Foi um assunto que, mal-grado as diversas queixas e resoluções, manteve-se sempre presente na sociedade portuguesa medieval, pois os judeus desempenharam continuamente papéis de destaque na administração pública a próprio pedido dos monarcas, que reconheciam a sua preponderância em assuntos financeiros e científicos, levando muitos a adquirir um conjunto de privilégios que ultrapassava, até, o de muitos cristãos cortesãos ${ }^{64}$.

${ }^{60}$ Manuscrito disponível em <http://rnod.bnportugal.gov.pt/rnod/winlibsrch. aspx ? \&pesq $=3 \& d o c=221376>$ [acesso a 02/03/2021]; $c f$. Maria José Ferro TAvares, Os Judeus em Portugal no Século XVI (2a ed. Lisboa: Guimarães Editores, 2000) pág. 66.

61 Tradução de Ferreira, Estatuto Jurídico, pág. 90.

${ }^{62}$ Fortunato de Almeida, História da Igreja em Portugal, vol. 1 (Coimbra, 1910) pág. 473.

63 Ferreira, Estatuto Jurídico, pág. 246.

64 Tavares, Os Judeus em Portugal no Século XV, vol. 1, pág. 215 e ss. 
A conversão ao Cristianismo mereceu também a atenção dos legisladores de 1211, tendo-se outorgado duas disposições em concordância com a prática canónica de que já falamos. Procurava-se, então, garantir a herança dos filhos neófitos, contrariando assim o que certos autores rabínicos - sob o signo do combate ao proselitismo judaico - promulgavam a respeito do seu deserdamento ${ }^{65}$. Aliás, algumas notícias oriundas de vários locais nesta Europa de Duzentos traduzem uma preocupação constante por parte dos judeus em evitar com que os seus companheiros procurassem a conversão ao Cristianismo, chegando a adoptar medidas mais drásticas ${ }^{66} \ldots$ : em Northampton, na Inglaterra de 1236, sabendo de antemão do baptismo do judeu Fernim de Amien e da sua família, vários vizinhos judeus raptaram as crianças do casal, como forma de prevenir que os «pequenos inocentes» fossem levados a cometer tamanho acto de traição ${ }^{67}$.

Mas o assunto que inspirava as maiores doses de repreensão e punição era, sem surpresa, o retorno ao antigo credo por parte dos conversos, como já tinha sido expresso na lei canónica e seria novamente estabelecido no $4^{\circ}$ Concílio de Latrão de $1215^{68}$. Porque a apostasia não era tolerada nem pela Igreja, nem pelos poderes seculares, por tratar-se duma infracção de maior ordem - mais do que um crime contra os homens, um crime contra Deus -, inspirava uma penalização particularmente dura. A lei de 1211 promulgava, deste modo, a pena capital para todos os que voltassem ao antigo credo depois de se converterem à fé de Cristo; porém, não recolhemos quaisquer registos que atestem à prática desta penalização, o que não implica, à partida, que não tivesse sido empregue pela justiça daquele tempo; mas é um tema que ainda hoje inspira dúvida entre os especialistas ${ }^{69}$.

Porém, a imagem mal-amada que gozavam os conversos medievais, além de se inspirar nas supostas motivações obscuras que ladeavam a

\footnotetext{
65 Tavares, Os Judeus em Portugal no Século XV, vol. 1, pág. 433.

66 TARTAKoff, «Testing Boundaries», pág. 752.

${ }^{67}$ STACEY, «The Conversion of Jews», pág. 738.

68 Ferreira, Estatuto Jurídico, pág. 149.

69 Sobre a prática da pena de morte, consulte-se Luís Miguel DuArTe, «Um luxo para um país pobre? A pena de morte no Portugal medievo», Clio \& Crimen 4 (2007) págs. 63-94.
} 
sua conversão ao Cristianismo, tinham que ver, essencialmente, com as notícias da sua apostasia. Há inúmeros exemplos de escárnio cujo significado provém desse mesmo facto, como veremos adiante. Mas aproveitemos para recordar, a este propósito, os versos apimentados de Álvaro de Brito Pestana, que mais tarde seriam compilados no Cancioneiro Geral de Resende: «Sam marranos os que marram /nossa fee, mui infieeis, / bautizados, / que na lei velha s'amarram / dos negros Abravanees / doutrinados» ${ }^{70}$.

\section{Tornadiços e CÃEs RENEGados}

Quem quer que se debruce sobre as principais colectâneas jurídicas do período medievo, procurando traçar o perfil legal do judeu português, será confrontado com vários testemunhos do eco popular face às conversões ao Cristianismo -que sabemos terem sempre despontado casos mais ou menos graves de descontentamento por ambas as partes. É difícil, porém, aferir as origens exactas destas práticas.

A tradição consuetudinária - os chamados foros e costumes, cuja própria natureza impede cálculos precisos em relação à sua origem ${ }^{71}$, atesta à prática, em Beja e noutros lugares, de «quem chamar tornadiço ao que era doutra leey e se uolueu christaão pague LX soldos ao alcayde...». Procurando explicitar os contornos deste insulto (tornadiço), depressa apercebemo-nos da sua utilização nos reinos hispânicos vizinhos, onde ««viven et mueren muchos homens en las creencias extrañas que amarien seer cristianos, sinon por los aviltamentos et las dehonras que veen recibir de palabra et de fecho á los outros que se tornar cristianos, llamándolos tornadizos, et porfazándolos en muchas maneras de demuestos» ${ }^{72}$. E à semelhança do costume de Beja, a lei castelhana punia a palavra injuriosa lançada contra os que se convertiam ao Cris-

70 Composição incluída no Cancioneiro Geral. Ordenado por Garcia de Resende (Lisboa, 1516) fl. 26하. $c f$. António José SARaiva, The Marrano Factory, trads. H. P. Salomon e I. D. S. Sassoon (Leiden: Brill, 2001) pág. XV, nota 4.

71 Mário Viana, «Um testemunho de Direito Consuetudinário (1281)», Revista Arquipélago. História 6 (2002) págs. 399-415: 399-400.

72 Partida VII, Título XXV “De los moros”, Ley III; cf. Las Siete Partidas, pág. 677. 
tianismo; havia, pois, que respeitar os que, por sua própria e livre vontade, usualmente deixando para trás os costumes em que nasceram e cresceram, incluindo os seus familiares mais próximos, abraçavam a fé de Cristo $^{73}$.

O escárnio de judeus contra os conversos é um fenómeno bem conhecido da crítica estrangeira, havendo em Portugal poucos exemplos elucidativos, pelo menos para o período considerado. Nas Partidas de Afonso X, o Sábio, uma lei determinava, inclusivamente, que os judeus não deviam molestar os que se tornam cristãos, sendo os delinquentes punidos com a pena capital ${ }^{74}$.

Mas não há como ignorar o caso peculiar de um insulto que surge na documentação de Duzentos, e que serve de epígrafe para este texto: o «cam renegado» - e que me parece uma prova mais do que elucidativa de que, de facto, também os judeus participavam no escárnio dos conversos. Exactamente por abandonarem os seus antigos irmãos de fé, normalmente em circunstâncias pouco clarificadas, mas sempre relacionadas com um relativo mal-estar dentro da comunidade, os conversos sofriam na pele os insultos e a violência dos seus antigos companheiros - e isso traduzia-se, por sua vez, no próprio escárnio cristão. Ora, a expressão considerada - «cam (ou cão) renegado» - relaciona-se, primeiro e mais directamente, com a imagética associada ao judeu medievo ${ }^{75}$, que normalmente era representado como uma figura amordaçada, de feições caninas, com orelhas e focinho animalescos, vestindo o característico chapéu cónico -como demonstra bem uma escultura trecentista localizada no pórtico da Sé de Évora (Figura 1).

73 «Porque todos deben honrar á estos atales por muchas razones, et non deshonralos; lo uno es porque dexan aquella creencia em que nascieron ellos et su linage; et lo al porque desque han entendimiento conoscen la lejoria de la nuestra fe, et recíbenla et apártanse de sus padres, et des sus madres, et de los otros sus parientes et de la vida que habien acostumbrado de facer»: Partida VII, Título XXV "De los moros", Ley III; $c f$. Las Siete Partidas, pág. 677.

74 Partida VII, Título XXIV “De los judíos”, Ley VI; cf. Las Siete Partidas, págs. 672-673, e Ferreira, Estatuto Jurídico, pág. 202.

75 Sobre isto, veja-se o recente trabalho -muito elucidativo-, de Gabriela BENNER, Ivdaevs. Construcción de una imagen en el arte europeo occidental (Siglos XIII al XVI) (Porto: Faculdade de Letras da Universidade do Porto, 2019). 


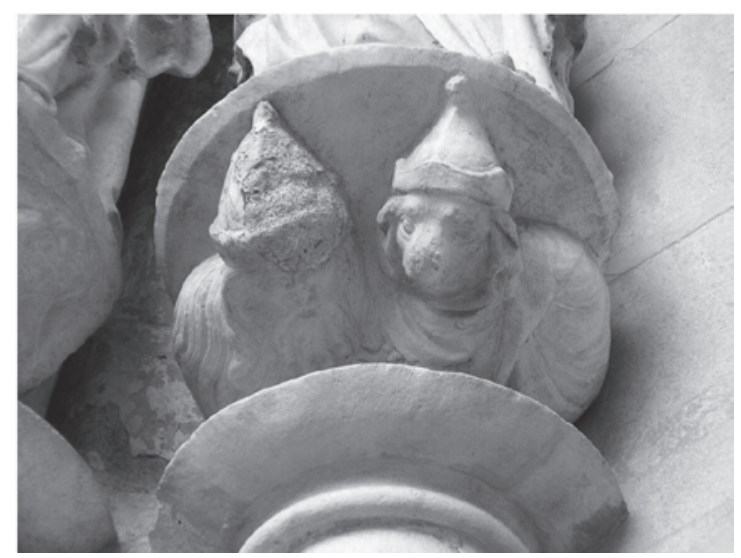

Fig. 1. Pórtico da Sé de Évora (detalhe)

Trata-se, no fundo, dum insulto que atesta ao estatuto mal-amado desses conversos, sugerindo, pois, a sua rejeição tanto por parte da sociedade cristã que tentavam integrar, como também por parte dos próprios judeus, que olhavam com desdém para o acto traiçoeiro da sua conversão ao Cristianismo, e consequente renúncia à tradição milenar que carregava o povo eleito de Deus.

\section{Dois casos de CONVERsão}

Longe de serem os únicos, por ainda não se terem reunido esforços para conduzir uma pesquisa exaustiva pela documentação ducentista e trecentista, e longe de serem inéditos, por já merecerem a sua divulgação em outros trabalhos, há dois testemunhos da conversão de judeus ao Cristianismo que merecem ser destacados, quer pela riqueza dos seus relatos individuais, quer pelo modo como se enquadram no panorama teológico e legal que temos visto.

$\mathrm{O}$ primeiro caso, à partida o mais obscuro, pelos seus tímidos contornos, trata dum frade de Alcobaça que, a julgar pelo seu registo onomástico, parece sugerir-nos um passado judaico: falamos de frei Domingos Soares Hebreus, identificado por Saul António Gomes ${ }^{76}$; mas a vida passada deste

76 Gomes, «Os Judeus no Reino Português», pág. 13. 
indivíduo permanece uma completa incógnita, para além daquilo que as meras hipóteses parecem sugerir: que este judeu convertera-se ao Cristianismo por acção dos monges alcobacenses, que o introduziram ao ora et labora do quotidiano monástico; parece-me a tese que melhor explica esta ocasião. Aliás, é bem conhecido o caso de muitos monges que, antes de vestirem o hábito, seguiam a fé mosaica. Há o exemplo de Teobaldo de Norwich, que se viu envolvido no célebre caso do assassinato de Guilherme de Norwich, cuja morte foi atribuída à responsabilidade judaica. Mas sabese igualmente que nessa Inglaterra do século XIII, o baptismo dos judeus não figurava no programa beneditino, cisterciense e agostiniano ${ }^{77}$. Em Portugal, por via da escassez de estudos sobre esta temática, não podemos tecer certezas a esse propósito, permanecendo um campo aberto para futuras investigações.

Por outro lado, o segundo testemunho, embora não isento das suas próprias dúvidas, surge-nos como o mais completo à data. $\mathrm{O}$ registo parte de dois textos medievais que já mereceram ampla divulgação e estudo crítico: o Livro Velho de Linhagens e o Livro de Linhagens do Conde Dom Pedro; o primeiro, redigido algures por volta de 1270 por um autor anónimo ${ }^{78}$; o segundo, atribuído à pena de Dom Pedro, Conde de Barcelos, que o compilou entre 1340 e $1344^{79}$. Pese embora os quase setenta anos que medeiam ambas as produções, parece seguro supor que este último mantivesse um contacto próximo com a tradição literária do Livro Velho, o que se torna claro neste e em muitos outros exemplos, entre confirmações e outras tantas contradições, como tem sido explicitado por vários especialistas ${ }^{80}$. Comparemos, então, ambos os registos:

77 STACEY, «The Conversion of Jews», pág. 266.

78 Augusto B. da Costa VeigA, «Os Nossos Nobiliários Medievais: alguns elementos para a cronologia da sua elaboração», Anais das Bibliotecas e Arquivos 2, vol. 15 (1942) págs. 165-193; José Carlos Ribeiro Miranda, «Do Liber Regnum em Portugal antes de 1340», e-Spania 9 (2010, em linha <https://journals.openedition.org/e-spania/19315> [acesso a 20/02/2021]).

79 Maria do Rosário Ferreira, «A estratégia genealógica de D. Pedro, Conde de Barcelos, e as refundições do Livro de Linhagens», e-Spania 11 (2011, em linha $<$ https:// journals.openedition.org/e-spania/20273> [acesso a 20/02/2021]), e Pedro de Barcelos e a Escrita da História (Porto: Estratégias Criativas, 2020) passim.

80 À data da publicação deste artigo, o Livro de Linhagens do Conde D. Pedro, juntamente com outros aspectos da sua vida política e literária, é alvo de estudo da parte 
Gonçalo Paes Taveira casou com a filha de Rui Fernandes Capom, que foi filho de Rui Capom, que foi [judeu], e fege-o cavaleiro rei dom Afonso, e houveram dous filhos e uma filha; e um houve nome Lourenço Gonçalves e houve filhos e filhas; e outro filho houve nome Rui Gonçalves de Taveira, e foi casado e houve filhos... ${ }^{81}$

Este Gonçalo Paaez Tavveira foi casado com dona Maria Rodriguez, filha de Rui Capom, que foi judeu, e veo a esta terra com rainha dona Orraca por seu almoxarife, e depois feze-o ela bautizar, e poserom-lhe nome Rodrigo, e por sobrenome Rui Capom; e fez a el rei dom Afonso, seu marido, filho d'el rei dom Sancho, o segundo ${ }^{82}$, o Velho, rei de Portugal, que o feze cavaleiro, e andou e sa casa, e trouve i sa filha mui fermosa de Castela, e feze-a bautizar consigo, e pose-lhe nome Maria Rodriguez. E Rui Capom era de mui grande algo e deu mui grande riqueza a Gonçalo Paaez Taveira, que casasse com ela, e el casou com ela e fez em ela Lourenço Gonçalvez e Rui Gonçalvez. E Rui Capam, casou-o a rainha em Lixboa com ua cidadãa rica, e fez em ela Gil Rodrigues, que foi arcediago de Lixboa... ${ }^{83}$.

Como vemos, a notícia desenrola-se em torno da figura de Rui Capão, apesar da ambiguidade com que surge em ambos os registos. É fácil notála: enquanto o Livro Velho atribui-lhe uma descendência de duas gerações (a filha de Rui Fernandes Capom, que foi filho de Rui Capom, que foi [judeu]), o Livro de Linhagens omite a figura de Rui Fernandes Capão, estabelecendo, por seu turno, uma relação paternal entre o judeu converso e a esposa de Gonçalo Pais Taveira. Não raras vezes surgem casos semelhantes nos nobiliários medievais, pelo que há duas hipóteses explicativas

do Projecto «MELE: Da Memória Escrita à Leitura do Espaço», onde se inclui a reedição da sua magnum opus em formato digital, acompanhada naturalmente da publicação de estudos filológicos e históricos. Veja-se $<$ https://pedrodebarcelos.wixsite.com/mele $>$ [acesso a 20/02/2021]. Aproveito para tecer os mais profundos agradecimentos ao Professor José Carlos Miranda (FLUP/IF) e ao Doutor João Paulo Martins Ferreira (FLUP/ IF) pelas observações que fizeram a respeito do testemunho de Rui Capão.

81 Publicado em Portugaliae Monumenta Historica (Nova Série), Livros Velhos de Linhagens, eds. Joseph Piel e José Mattoso (Lisboa: Academia das Ciências de Lisboa, 1980) pág. 57.

${ }^{82}$ Este designativo refere-se a «Dom Sancho, segundo rei de Portugal», e não a «Dom Sancho, o segundo».

83 Publicado em Portugaliae Monumenta Historica (Nova Série), Livro de Linhagens do Conde D. Pedro, vol. II, ed. José Mattoso (Lisboa: Academia das Ciências de Lisboa, 1980) pág. 489. 
para o esclarecimento desta ambiguidade: ou estamos perante uma omissão voluntária e ponderada por parte do Conde Dom Pedro, ou talvez tivesse havido uma confusão de natureza onomástica, dada a visível homonímia entre o Rui Capão e o Rui Fernandes Capão, donde se denota a queda do patronímico deste último, gerando-se a dita ambiguidade. Confusão gerada por mero descuido do Conde Dom Pedro, ou antes uma omissão premeditada? A dúvida permanece em aberto.

Certo é que este relato do Livro de Linhagens acrescenta valiosas informações ao retrato de Rui Capão, incluindo o tão-importante motivo que o levou a abraçar a fé Cristã. Ora, dada a sua condição étnica, ao judeu Rui Capão estaria vedado o exercício das suas funções enquanto almoxarife da rainha, à luz das recém-outorgadas leis de 1211; recordese que, embora estejamos a contemplar um registo manuscrito datado entre 1340 e 1344, o relato histórico impulsiona-nos para o alvorecer do século XIII, durante o reinado de Dom Afonso II, esposo da dita rainha Dona Urraca, castelhana. Portanto, há que suspeitar que, como forma de manter o seu cargo, a rainha «feze-o ella bautizar», assegurando, assim, os serviços do almoxarife que trouxe consigo de Castela, agora convertido à Fé de Cristo. Fazia-se cumprir a lei. Essencialmente.

Seguindo, pois, para o baptismo da sua filha, que adoptou o nome Maria Rodrigues ${ }^{84}$, não deixamos de sublinhar o carácter sentimental deste registo: o Conde Dom Pedro, assim, faz sobressair um nítido sentimento paternal, pois a conversão conjunta entre pai e filha permitia que ambos pudessem manter um relacionamento próximo, no círculo familiar e íntimo; pois a lei canónica e civil, como vimos, não consentia a convivência próxima entre judeus e cristãos, fosse de cariz sexual ou não. E especialmente quando se tratava de conversos, por receio duma eventual apostasia da parte do judeu recém-baptizado, à luz das recorrentes tentativas da parte judaica para fazê-lo retornar à antiga Fé.

O relato do Conde Dom Pedro segue depois com a celebração do matrimónio de Maria Rodrigues com um fidalgo da corte, Gonçalo Pais Taveira - que Rui Capão, agora cavaleiro de El-Rei, «deu mui grande riqueza (...) que cassasse com ela». Um suborno, naturalmente, a condi-

84 Note-se inclusivamente como o próprio patronímico respeita a prática onomástica corrente: «Rodrigues», filha de Rodrigo (ou Rui). 
zer com a imagem que contornava o judeu medieval, agiota e usurário, mas também rico e influente, cujo sucesso era atribuído ao volume da sua riqueza material. Com isto, denotamos também um pequeno nuance da psicologia do próprio Rui Capão que, embora convertido ao Cristianismo, mantém os velhos hábitos associados à sua condição anterior. Isto reveste-se de uma importância acrescida quando contemplamos a linguagem irónica do próprio Conde Dom Pedro, que, de acordo com a opinião de José Augusto Pizarro, «mais do que querer desprestigiar os Taveiras, condenando a cobiça de Gonçalo Pais, o qual não recusou a aliança com uma judia porque o pai a dotou largamente - o Conde afirma abertamente que foi bem pago para que casasse - pretendesse atingir a prosápia de Dom Lopo Fernandes Pacheco, o grande e poderoso valido de D. Afonso IV, o qual tinha casado com uma bisneta daquele...» ${ }^{85}$.

Em jeito de epílogo, Rui Capão toma novamente o casamento, desta vez com uma cidadã rica de Lisboa, por influência da própria rainha - talvez por compensação de algum serviço, como aliás era frequente. E deste último matrimónio gerou-se um filho: Gil Rodrigues, que foi arcediago de Lisboa, o que não deixa de carregar a sua dose de singularidade, até porque a nomeação de descendentes de judeus a cargos eclesiásticos era proibida pelo direito canónico, à luz das determinações de Gregório $\mathrm{IX}^{86}$. Inclusivamente, há que notar a figura dum Gil Rodrigues Capão na cronologia indicada; porém, ao invés de ocupar o seu cargo em Lisboa, surge como arcediago de Santarém, entre 1237 e $1243^{87}$. Será suficiente para confirmar a veracidade deste relato? Quem sabe, quem acerta?

De qualquer modo, a interpretação do registo literário faz sobressair ainda outra asserção: a de que este último filho de Rui Capão poderá também ser interpretado como um símbolo da tão-desejada integração,

85 José Augusto de Sottomayor-Pizarro, Linhagens Medievais Portuguesas: genealogias e estratégias (1279-1325), vol. I (Porto: Faculdade de Letras da Universidade do Porto, 1997) pág. 435, nota 6.

86 Ferreira, Estatuto Jurídico, pág. 161.

87 Foi graças à amabilidade do meu amigo André Rodrigues (U. Porto) que consegui aferir estes dados; estendo-lhe, por isso, os mais sinceros agradecimentos; $c f$. Ana Maria C. M. Jorge, Bernardo de Sá Nogueira, Filipa Roldão e Mário Farelo, «La dimension européenne du Clergé de Lisbonne (1147-1325)», em A Igreja e o Clero Português no contexto Europeu (Lisboa: Centro de Estudos de História Religiosa/Universidade Católica Portuguesa, 2005) págs. 17-43: 38. 
social e moral, da parte dum descendente de um judeu, entretanto convertido ao Cristianismo, como se a redenção do percurso anterior de Rui Capão estivesse finalmente completada neste último momento da sua vida, quando o seu filho, nascido e criado cristão, toma a responsabilidade de servir a causa de Deus, única e verdadeira.

\section{Epílogo}

Falou-se do panorama historiográfico minguado para as cronologias mais afastadas, naquilo que aos judeus conversos portugueses diz respeito - cuja razão de ser, como vimos, tem que ver essencialmente com a escassez de testemunhos, facto que obriga o historiador a tecer hipóteses e explicações com base num rol reduzido de documentos. De facto, o converso português é tímido: teima em não figurar com a frequência desejada na documentação escrita dos séculos XII e XIII, mal-grado a necessidade futura de conduzir uma renovada e exaustiva pesquisa documental: sem dúvida um esforço colectivo de grande envergadura, mas de imperiosa necessidade. Conhecemos o converso fundamentalmente através das fontes do Direito, que até ao momento inspiraram poucas concretizações por parte dos especialistas. Mas as próprias leis, canónicas e civis, pese embora o seu reduzido número, traduzem as claras preocupações dos legisladores de então, podendo ser resumidas em três pontos fundamentais:

1) a procura por conversões honestas e desprovidas de qualquer coacção forçosa da parte de que convertia;

2) a promoção de medidas que visavam acolher o converso na malha social comum, quer pela tutoria activa por parte de um ou mais cristãos, quer na garantia da sua devida herança familiar, mesmo que contrariasse a vontade dos seus parentes; mas, como vimos, nem sempre estas asserções teóricas resultaram em contornos práticos;

3) o combate ao baptismo desonesto e às práticas judaizantes de muitos conversos, penalizadas com a pena capital.

Destacou-se ainda um conjunto elucidativo de insultos que atestam ao estatuto mal-amado que gozavam os conversos medievos, e cujo escárnio provinha não só do partido cristão que tentavam integrar, como 
também dos seus antigos irmãos de fé, sendo por isso considerados autênticos «cães renegados», deambulando na esfera do desabono, à margem dos próprios marginalizados.

Por fim, vimos o caso de duas conversões ao Cristianismo, cujos contornos ainda bastante brumosos parecem, de facto, estar em concordância com aquilo que a lei determinava, o que não surpreende; mais ainda, o testemunho de Rui Capão permite-nos, com recurso, também, ao exercício de muitas hipóteses, conhecer melhor certas características da mentalidade medieval face aos conversos, mesmo que isso signifique a esfera particular de um só indivíduo (neste caso, o Conde Dom Pedro). Porém, embora estejamos a caminhar sob meras suposições baseadas num texto literário que lança inúmeros desafios hermenêuticos, já muito conhecidos, permita-me o leitor recordar, neste último momento, as palavras do saudoso Professor Carlos Alberto Ferreira de Almeida, a propósito dum trabalho seu, também envolto em muitas incertezas: «Faltam-nos muitos elementos para podermos ter uma noção segura sobre a evolução deste período; mas onde escasseiam as certezas têm direito, cientificamente, as hipóteses» ${ }^{88}$. Espero somente não ter abusado deste conselho.

Recibido: 03/11/2020

Aceptado: 12/04/2021

${ }^{88}$ Carlos Alberto Ferreira de AlmeIDA, «Notas sobre a Alta Idade Média no Noroeste de Portugal», Revista da Faculdade de Letras: História 3 (1973) págs. 113-138: 113. 